\title{
Design of an Interactive Module Based on the van Hiele Model: Case Study of the Pythagorean Theorem
}

\author{
Juan Roldán-Zafra ${ }^{1 *}$ (D), Carmen Perea ${ }^{1}$ (D), Irene Polo-Blanco ${ }^{2}$ (D) , Pedro Campillo $^{1}$ (D)
}

\author{
${ }^{1}$ Miguel Hernández University, SPAIN \\ ${ }^{2}$ Cantabria University, SPAIN \\ *Corresponding Author: jroldan@umh.es
}

Citation: Roldán-Zafra, J., Perea, C., Polo-Blanco, I. \& Campillo, P. (2022). Design of an Interactive Module Based on the van Hiele Model: Case Study of the Pythagorean Theorem. International Electronic Journal of Mathematics Education, $17(1)$, em0672. https://doi.org/10.29333/iejme/11556

\begin{tabular}{|c|c|}
\hline ARTICLE INFO & ABSTRACT \\
\hline Received: 18 Oct. 2020 & The recent increase in the number of mathematics museums has given rise to a need for tools with which to design \\
\hline Accepted: 24 Dec. 2021 & $\begin{array}{l}\text { and assess mathematics educational proposals in this non-formal context. This study proposes the use of the van } \\
\text { Hiele model, a benchmark in mathematics instruction, for the design of interactive museum models focusing on } \\
\text { mathematics content in general. By way of example, the model is characterised for application to the Pythagorean } \\
\text { theorem. An interactive module designed around the aforementioned characterisation for teaching the theorem } \\
\text { at the Museo Didáctico e Interactivo de Ciencias [interactive science instruction museum, MUDIC] may serve as a } \\
\text { reference for future interactive modules and workshops in museums dealing with any manner of mathematics } \\
\text { content. }\end{array}$ \\
\hline
\end{tabular}

Keywords: van Hiele model, mathematics instruction, Pythagorean theorem

\section{INTRODUCTION}

In the last 50 years we have been observers of the proliferation of science museums and science centers that rose up in response to the challenge of a necessary scientific literacy of our society. Normally, we come across displays in science museums from all areas of the scientific and technological field. However, if we focus on mathematics, it is possible to notice that it has been present in the evolution of science centers either with the exhibition of devices and tools, with sections that introduce mathematical concepts and procedures, or with participatory workshops. It is also interesting to highlight the increased attention in strengthening the knowledge of mathematics in society, which is reflected in the creation of museums exclusively dedicated to the learning of mathematics. Thus, there are several examples as MOMATH in New York (USA), Mathematikum in Giessen (Germany), MMACA Museum of Mathematics in Cornellà (Spain), Museum of Mathematics in Seoul (Korea), The Garden of Archimedes in Florence (Italy), Haus der Mathematik in Vienna (Austria), or NAVET in Borås (Sweden), among others around the world.

The efficacy of a casual environment in science learning has been studied in depth. We have found inter alia the following studies that confirm it: Allen (2004), Anderson et al. (2003), Falk and Dierking (2013), Griffin (1998), Guisasola et al. (2005), Hein (1998), McManus (1992), Rennie and Johnston (2004), Salmi (2003), and Tuckey (1992). Any list attempting to compile all the literature on the subject will leave out key projects. It is vital to underline that it is possible to find published essays specifically mentioning mathematics learning in museums (Popovic \& Lederman, 2015; Suter, 2014).

On the basis of the above, the aim of this article is to carry out the methods that allow us to design an interactive module for learning the Pythagorean theorem during a visit to a science museum. By this way, we work in a double aspect, considering that the module focuses on the content we want to teach, but the participant interaction will be through challenges set out to the visitor, turning the experience into a motivating game (Perry, 1992). The level model for Geometry learning described by van Hiele $(1955,1986)$ provides us a theoretical foundation to tackle the content of the module in the design. This model is considered a reference in the sphere of mathematics education, and it has served as a basis both for the structuring and evaluation of the teaching of mathematical content and for the educational design of this subject at both Primary and Secondary levels (Gutiérrez \& Jaime, 1998). Furthermore, an explicit characterization of this model has been proposed for a better orientation in its application, considering both the description of the levels and the skills identified by Hoffer (1981).

The project is structured as follows. The first section presents a literature review in which gathers different research focused on learning in museums with special emphasis on science and mathematics museums; summarizes the main characteristics of 
van Hiele's model of mathematical reasoning as well as the main research that explains and evaluates students' reasoning based on this model; to end the section, concentrates on the learning of the Pythagorean theorem where research related to historical and educational aspects has been collected. The second section defines the used methodology. The third section proposes an explicit characterization of van Hiele's model for learning this theorem considering the skills identified by Hoffer (1981). This characterization has been applied to design an interactive module of the Didactic and Interactive Science Mseum MUDIC-VBS-CV focused on the learning of this mathematical content. Finally, the fouth and fifth sections present the discussion, conclusions and future lines, respectively.

\section{LITERATURE REVIEW}

\section{Learning in Museums}

Interest in museum-based learning has been on the agenda practically since public museums were first instituted. That interest is mirrored in different types of studies: from historic research on the impact and educational value of museum visits (Hein, 1998) to papers focusing on methodologies for assessing the impact of such learning (Falk \& Dierking, 2013). The number of science museums in particular has skyrocketed since the nineteen sixties. These constantly developing institutions have been usefully and simply classified by their underlying philosophy.

The number and variety of studies has risen in keeping with the number of institutions. Guisasola and Morentín (2007) published a review of the literature on the educational role of school visits to museums in 2007. Brajčić et al. (2013), exploring students' opinions of learning in museums, concluded that pupils value such learning highly, regarding it as efficient and necessary to their education. They also concluded that their findings should serve to further closer cooperation between museums and educational institutions.

Faria et al. (2015) drew similar conclusions from experiences with primary school pupils in two science museums. Allen (2004) addressed the difficulty entailed in designing museum content for conveying scientific concepts and the immense amount of research and assessment involved in the process. Anderson et al. (2000) conducted a study on how to teach electricity and magnetism by supplementing classes with activities in a science museum and others associated with the moduli visited in museums, stressing the importance of preparing pre- and post-visit activities.

Moreover, measuring the impact of a museum module on visitors is a complex task, among others because the latter do not always use the information provided during the visit as initially intended. The papers reviewed for this study reported that whilst students could acquire factual and conceptual information after interacting with a series of modules on related scientific concepts, significant conceptual development only took place when the visit explicitly addressed learning objectives that associated classroom activity with the museum visit (Falk, 1997). Hence the importance of coordinating the visit with classroom activities before and after.

Guisasola and Morentín (2007) concluded from their review of the literature that student visits to science museums must be mainstreamed in classroom planning for learning to embrace more than sheer attitude. Teachers organising such outings with their students should prepare and adapt the museum's offering to their own teaching objectives.

The design of student visits that bridge classroom (curricular) and non-formal (scientific literacy) learning is no easy or obvious task and calls for cooperation among museum educators, teachers and science education researchers. It also requires teacher training. Studies such as conducted by Chin (2004) or Guisasola and Morentín (2015b) discuss the resources and training offered by museums to science teachers planning a museum visit, as well as the activities before, during and after such visits to optimise science museum-based learning.

In this vein, Guisasola and Morentín (2015a) stressed the importance of structuring visits to favour student learning and of reinforcing the connections between the museum experience and pre- and post-visit classroom activities. Insofar as the ultimate aim is to favour learning, the general structure of activities proposed by those authors is as follows: (1) activities and resources prior to the visit (pre-visit); (2) interactive activities or pursuit of information during the visit; and (3) post-visit activities to reflect on the experience.

\section{Learning Geometry: van Hiele Model}

A good deal of research conducted to explain how students learn geometric concepts has been based on the van Hiele geometric reasoning model (Gutiérrez \& Jaime, 1998; Jaime, 1993; Jaime \& Gutiérrez, 1990; Sarasua, 2010). Moreover, this model, first introduced in 1955, has significantly impacted the development and implementation of the curricula in many countries (the Soviet Union in the nineteen sixties, The Netherlands and the United States in the nineteen seventies and Spain in the nineteen eighties) (Jaime, 1993).

An updated version of the model published in 1986 assumes the existence of four levels of reasoning to characterise an individual's geometric thinking, namely: (1) visualisation; (2) analysis; (3) abstraction; and (4) deduction. Although these are the four levels normally assumed, a fifth (rigour) is occasionally included. Researchers do not agree on how they should be numbered, however, whether from 1 to 4 or 0 to 3 (Jaime, 1993).

The major characteristics of this model are level hierarchy and sequence (levels may not be leap-frogged: the first must be mastered before advancing to the second and so on) and continuity in moving from one level to the next (with a transition period in which two levels of reasoning are combined (Campillo, 1998; Jaime \& Gutiérrez, 1990)). 


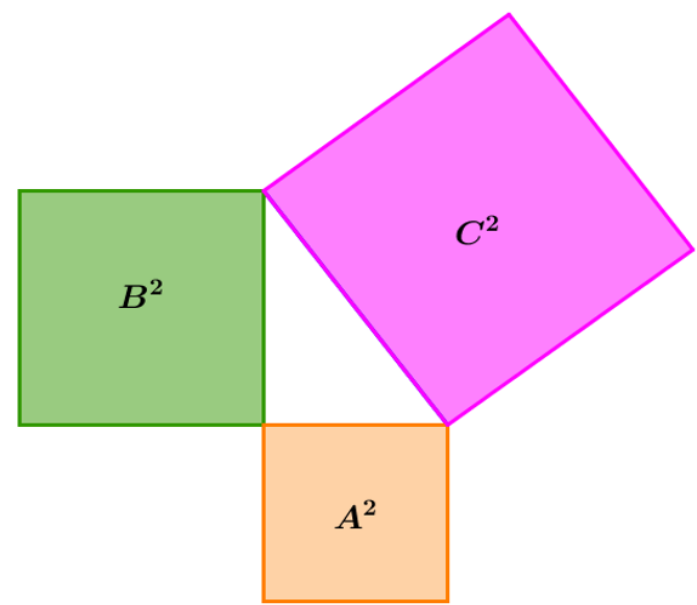

Figure 1. Geometric meaning of the Pythagorean theorem

Language and levels are also closely related. Each level has a specific language. The ability to reason associated with the van Hiele levels is revealed not only by how problems are solved, but also by how students express themselves and the significance attached to the specific vocabulary.

Moreover, the van Hiele model proposes learning phases including suggestions on how teachers may organise content that favours student progress from one level to the next. These phases are: (1) information; (2) guided orientation; (3) explicitation; (4) free orientation; (5) integration (Jaime, 1993; Jaime \& Gutiérrez, 1990):

(1) In the first or information phase the teacher informs students of the area of study to be broached. Here students acquire the basic knowledge needed to perform mathematical work. It also serves teachers as an information gathering exercise, in which they ascertain whether students have any prior knowledge of the topic at hand.

(2) In the second, guided orientation phase, students discover, understand and learn the main concepts and properties informing the area in which they are working. Here they build the basic elements of the relationship networks for the next level.

(3) In the third or explanation phase students exchange experiences, describing how they conducted the activities in a group sharing context. Another aim is for students to learn the vocabulary relating to the level of reasoning pursued.

(4) In the self-orientation phase, students apply the knowledge and language acquired to other types of investigation to perfect their understanding of the matter. Here the teacher poses problems that may be solved in different ways or lead to different solutions.

(5) Lastly, in the integration phase students should acquire an overview of the content and methods worked on, relating their new knowledge to other fields.

Since van Hiele published his proposal, many researchers have formulated instruments to assess students' levels of reasoning (Crowley, 1990; Usiskin, 1982). With a view to more accurate assessments, Gutiérrez and Jaime (1998) identified a series of key reasoning processes: (1) recognition; (2) formulation and use of definitions; (3) classification; and (4) proof, all four of which are applicable to all the van Hiele levels.

Another benchmark in the application of the van Hiele model was put forward by Hoffer (1981), who adopted an interesting perspective in an article entitled 'Geometry is more than proof'. Whilst Hoffer deemed that proofs are a significant component of geometry, he contended that syllabi should also stress other useful skills. He categorised geometric content into five, visual, verbal, drawing, logical and applied, and included them as a second dimension in the van Hiele levels. He proposed that instruction should support students' progress through the van Hiele levels in all the dimensions of geometric skills.

Hoffer (1981) contended that a student in van Hiele level 2 (analysis), for instance, should be able to visually identify a figure even when contained in another (visual skill), accurately describe the properties of a figure (verbal skill), draw figures based on their properties (drawing skill), understand that figures have characteristic properties (logical skill) and use figures and their properties to apply them to other realms (applied skill) (Hoffer, 1981).

\section{Pythagorean Theorem and van Hiele}

The following brief history of the Pythagorean theorem is supplemented with a discussion of its importance in the secondary curriculum and the methodological proposals to teach it. The focus is on research addressing the van Hiele model as a benchmark in such teaching paragraph

\section{The theorem and its proofs}

Pythagoras is often credited with authoring history's most famous theorem (Pérez, 2009). In the Middle Ages it was known as the pons asinorum or bridge of asses that anyone aspiring to be deemed as educated had to 'cross'.

The theorem contends that for any right triangle with sides $A, B$, and $C, C^{2}=A^{2}+B^{2}$. The geometric perspective of the theorem is based on a comparison of the areas of the squares formed over the sides of a right triangle, as in Figure 1. 
Any number of proofs for the theorem have been proposed throughout history using a variety of methods. Loomis (1968), a U.S. mathematician, described 370 such proofs. He also grouped them under four major headings: algebraic (relating the sides and segments of a triangle), geometric (comparing areas), dynamic (using mass and velocity) and quaternionic (deploying vectors).

The Pythagorean theorem is a fundamental item on secondary school curricula. Teaching the theorem is regarded as crucial not only for its educational but for its instrumental value (imperative to calculate distances and vectorial magnitudes). That would explain the many pedagogical studies that explore how the theorem and its proofs are learnt.

Several of those studies propose methodologies for teaching the theorem. Arrieta et al. (1997), for instance, postulated the use of manipulatives such as the geoboard, whilst Vargas and Gamboa (1997) proposed a method based on the use of GeoGebra (dynamic geometric software).

Many studies have used the historical proofs of the theorem as a teaching tool (Barreto, 2009; González Urbaneja, 2008; Gurrola \& Jáuregui, 2008; Weiss-Pidstrygach, 2007), focusing on geometric area comparisons. Such proofs can be posed in the form of geometric puzzles, affording students the opportunity to sharpen their visualisation skills by exploring multiple representations.

\section{Application of the van Hiele model to teaching the Pythagorean theorem}

Despite the significance of the van Hiele model in the design of school geometric content, very few studies propose to apply it to teach the Pythagorean theorem. In one of the exceptions, Vargas and Gamboa (2013) aimed to ascertain students' geometric reasoning through theorem-related activities, although the authors provide no descriptors for the reasoning levels.

Flores (1993), in turn, designed a lesson in which students develop their understanding of the Pythagorean theorem, level by (van Hiele) level. This author introduced a separate version of the Euclidean proof for each level.

\section{METHODOLOGY}

In this paper we go to introduce a proposal for the use of the van Hiele model as a theoretical tool for the design of modules, applied in this case, to the Pythagoras theorem. We also show the implementation of the module.

This research followed a developmental research approach (Wang \& Hanafin, 2005) focused on the development of an interactive module for teaching the Pythagorean theorem. The study followed the phases: analysis, design and development (Richey et al., 2004).

It begins by analyzing the environment, the MUDIC, where this study was conducted, is an interactive, educational science museum focusing on science and technology instruction in a non-formal environment. It is sited on a university campus and run by science and technology professors and teachers at all levels of education.

The museum has recreational science and renewable energy experiment halls and workshops, as well as a planetarium, a scientific garden with sundials at the building entrance and a vegetable garden. It receives secondary and primary school students. Pupils visit the experiment halls in groups of five accompanied by a monitor and participate in workshops likewise with monitors. The museum also organises related activities such as scientific conferences, stands at science fairs, scientific theatre and cinema, teacher training courses, science contests and scientific innovation symposia.

Against that backdrop, the MUDIC constitutes an ideal environment for conducting studies on museum-based learning. Its staff maintains close relations with teachers and researchers, as frequently recommended in studies on learning in non-formal environments. Moreover, the researchers are also teachers who form part of the module design team or participate in teacher training in this regard. Lastly, given the museum's on-campus location, these researchers cooperate or are familiar with the museum.

\section{Procedure}

In light of the paucity of studies associating the Pythagorean theorem with the van Hiele model, the following section characterises the model levels in conjunction with the skills defined by Hoffer (1981). That characterisation, which may serve to design modules for the various levels involved, is followed by a specific proposal for an interactive module to teach the Pythagorean theorem at the MUDIC.

The module will be divided into three stages: pre-visit, module and post-visit, in keeping with earlier proposals for structuring museum activities that favour student learning (see, for instance, Guisasola \& Morentín, 2015a). The stages are associated with the learning phases proposed in the van Hiele model and described in the previous section. The proposal helps students work on van Hiele's (1986) four levels of reasoning and the five skills identified by Hoffer (1981). Interaction with the monitors and the module is also envisaged at each stage.

\section{FINDINGS}

\section{Characterisation of the van Hiele Levels for Teaching the Pythagorean Theorem}

The following is a proposal for applying the van Hiele model to teach the Pythagorean theorem and its proofs. Summarised in Table 1, it consists in explicitly characterising the model's four levels of reasoning in terms of the five basic skills (visual, verbal, 
Table 1. van Hiele levels and Hoffer skills for the Pythagorean theorem

\begin{tabular}{|c|c|c|c|c|}
\hline Skill|Level & $\begin{array}{c}\text { Level } 1 \\
\text { Visualisation } \\
\end{array}$ & $\begin{array}{l}\text { Level } 2 \\
\text { Analysis }\end{array}$ & $\begin{array}{c}\text { Level } 3 \\
\text { Abstraction }\end{array}$ & $\begin{array}{c}\text { Level } 4 \\
\text { Deduction }\end{array}$ \\
\hline Visual & $\begin{array}{c}\text { Recognises different } \\
\text { triangles and angles in a } \\
\text { drawing }\end{array}$ & $\begin{array}{l}\text { Recognises right angles and } \\
\text { triangles, even when part of } \\
\text { larger figures }\end{array}$ & $\begin{array}{l}\text { Understands area congruence } \\
\text { referred to adding and subtracting } \\
\text { Understands visual proofs of the } \\
\text { Pythagorean theorem }\end{array}$ & $\begin{array}{l}\text { Understands relationships } \\
\text { among different visual proofs of } \\
\text { the Pythagorean theorem }\end{array}$ \\
\hline Verbal & $\begin{array}{c}\text { Associates triangle name and } \\
\text { figure } \\
\text { Interprets verbal } \\
\text { descriptions of triangles }\end{array}$ & $\begin{array}{l}\text { Describes right triangles on the } \\
\text { grounds of their components: } \\
\text { legs, hypotenuse, base, height, } \\
\text { right angle }\end{array}$ & $\begin{array}{c}\text { Formulates precise definition of a } \\
\text { right triangle } \\
\text { Formulates the Pythagorean } \\
\text { theorem in terms of the } \\
\text { relationship between the areas of } \\
\text { squares built over the legs and } \\
\text { hypotenuse }\end{array}$ & $\begin{array}{l}\text { Understands the Pythagorean } \\
\text { theorem as a necessary and } \\
\text { sufficient property to define } \\
\text { right triangles }\end{array}$ \\
\hline Drav & $\begin{array}{c}\text { Draws angles and triangles, } \\
\text { accurately labelling the } \\
\text { components }\end{array}$ & $\begin{array}{l}\text { Applies verbal information on } \\
\text { properties to draw right triangles }\end{array}$ & $\begin{array}{l}\text { Can build other figures from right } \\
\text { triangles }\end{array}$ & $\begin{array}{l}\text { Represents the Pythagorean } \\
\text { theorem pictorially based on } \\
\text { verbal information on proofs }\end{array}$ \\
\hline Logical & $\begin{array}{l}\text { Differentiates between } \\
\text { triangles and other } \\
\text { geometric figures } \\
\text { Understands the notion of } \\
\text { shape invariability despite } \\
\text { positional change in } \\
\text { triangles }\end{array}$ & $\begin{array}{l}\text { Understands triangle } \\
\text { classification based on legs and } \\
\text { angles } \\
\text { Identifies the square of the length } \\
\text { of the leg of a right triangle with } \\
\text { the area of the respective square }\end{array}$ & $\begin{array}{l}\text { Understands the consecutive } \\
\text { steps of a proof of the } \\
\text { Pythagorean theorem } \\
\text { Uses the reciprocal of the } \\
\text { Pythagorean theorem to } \\
\text { determine when a triangle is and } \\
\text { when it is not a right triangle }\end{array}$ & $\begin{array}{c}\text { Understands the need for proofs } \\
\text { to verify the Pythagorean } \\
\text { theorem } \\
\text { Can prove the Pythagorean } \\
\text { theorem using logical rules }\end{array}$ \\
\hline Applied & $\begin{array}{l}\text { Recognises examples of } \\
\text { triangles and angles in } \\
\text { physical objects }\end{array}$ & $\begin{array}{c}\text { Recognises the use of the } \\
\text { Pythagorean theorem in other } \\
\text { realms }\end{array}$ & $\begin{array}{c}\text { Can solve real life problems using } \\
\text { the Pythagorean theorem }\end{array}$ & $\begin{array}{l}\text { Develops mathematical models } \\
\text { involving the Pythagorean } \\
\text { theorem to represent abstract } \\
\text { systems or describe natural, } \\
\text { physical or social events }\end{array}$ \\
\hline
\end{tabular}

drawing, logical, and applied) identified by Hoffer (1981). As noted earlier, these skills characterise geometric knowledge in each of the van Hiele levels and can be explicitly described to structure the mastery of geometric content.

Table 1 was built as a matrix based on the four van Hiele levels and the five Hoffer (1981) model skills, drawing from a study by Jaime and Gutiérrez (1990). It describes the skills that can be developed by working with the interactive module and serves as a basis for module design and training and guidelines for monitors.

MUDIC museum visitors are essentially primary and secondary school students, most with level of reasoning 1 (visualisation) or 2 (analysis). The proposal includes a description of the four levels to enable students in the higher levels to continue to progress. It also aims to serve as a guide for designing other modules involving several levels of geometric reasoning.

\section{Design of the Visit and the Interactive Module}

\section{STAGE 1: Pre-visit}

The pre-visit concurs with the van Hiele information phase. As discussed previously, during this phase teacher conduct activity designed to ascertain students' prior understanding of the elements to be used in the module. To that end, in the classroom students are asked about geometric figures to determine whether they distinguish triangles and are aware of their properties. Where the visitors are non-school groups or the teacher has not engaged in the preliminaries, monitors talk to them about triangles, using vocabulary specific to their van Hiele level.

Early van Hiele level 1 students such as pre-schoolers are asked to pick out the triangles in photographs of a box, after having received a description of their characteristics. Their correct and incorrect answers are then discussed. Students in later years are shown illustrations of different angles which they compare and measure to distinguish right from other types of angles. They are then shown a large collection of triangles and asked to list their characteristic properties based on their legs or angles. The veracity of the Pythagorean theorem is then verified in different situations involving right triangles.

This stage addresses the Hoffer visualisation and analysis skills.

\section{STAGE 2: Interaction with the module (museum visit)}

This stage, geared to the van Hiele model guided orientation and explanation phases, consists in three activities. The estimated time for this stage is 15 minutes.

\section{First interaction with the module: Recognition of right triangles}

The monitor shows the students that when they fold the corner of a piece of paper the result is a right triangle. They are then asked to identify the right triangles in the drawing, set out on a table, depicted in Figure 2.

Visitors are then shown photographs of artistic or everyday objects and asked to identify different types of triangles. This first activity addresses the visual, verbal, logical and applied skills in levels 1 and 2, as well as the visual skill in level 3. 

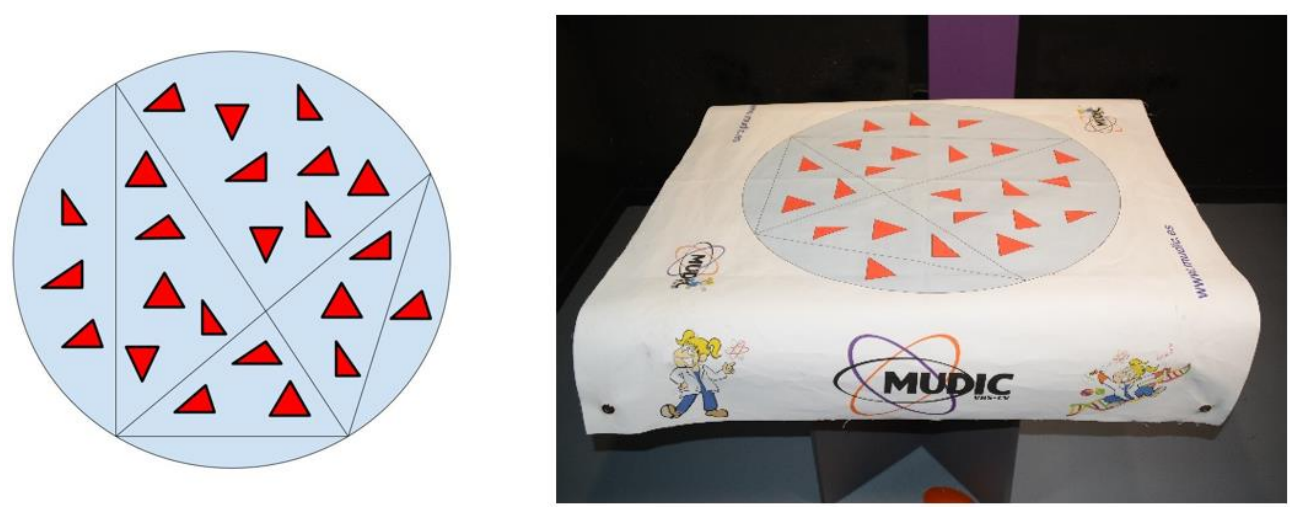

Figure 2. First activity: Recognition of right triangles design (left) \& Implementation (right)

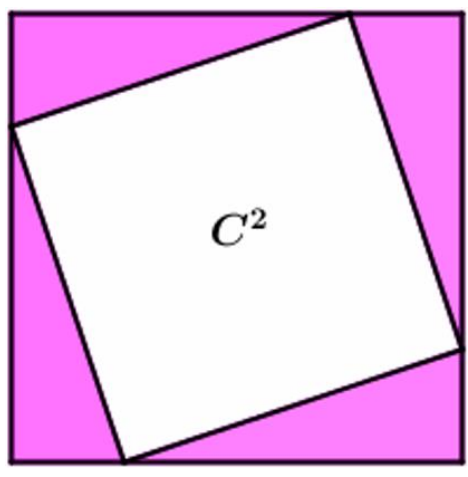

(a)

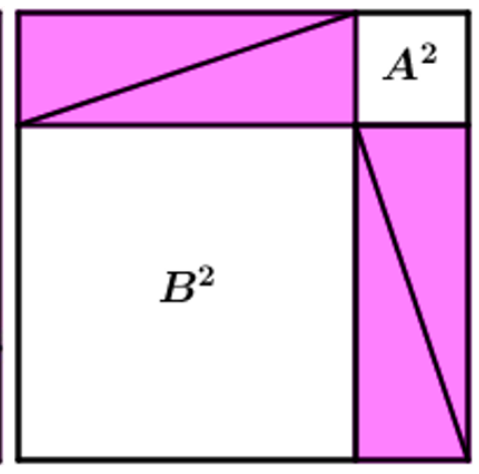

(b)

Figure 3. a) Proof attributed to Pythagoras ( $569 \mathrm{BCE}, \sim 475 \mathrm{BCE})$; b) Duly reorganised

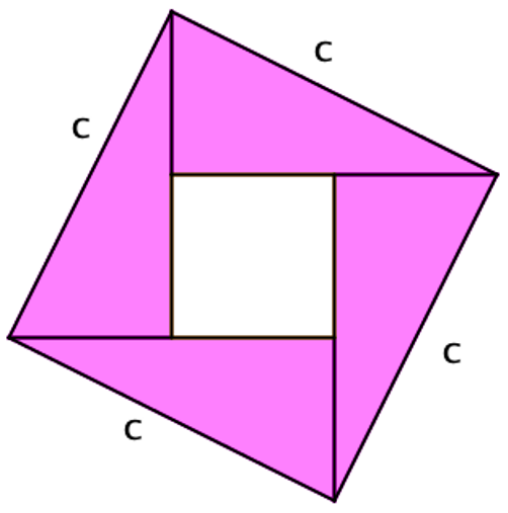

(a)

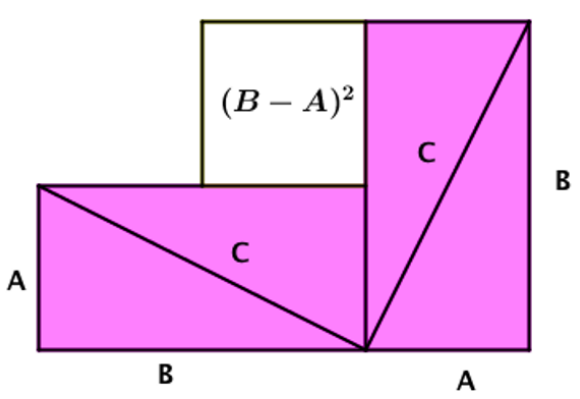

(b)

Figure 4. a) Proof authored by Bhāskara (1114-1185); b) Reorganised pieces

\section{Second interaction with the module: Puzzles for proving the Pythagorean theorem}

As an interactive museum, the MUDIC deems manipulatives to be essential to module-induced skill development. In this stage, monitor- or teacher-guided groups of students try to reconstruct a number of wooden puzzles that prove the Pythagorean theorem on a $50 \mathrm{~cm} \times 45 \mathrm{~cm}$ table.

These puzzles are based on proofs that compare the areas of congruent figures by addition or subtraction. The proofs chosen, which entail different levels of difficulty, are drawn from Loomis's (1968) or González Urbaneja's (2008) compilations. Two are described below by way of example. The first (Figure 3a) is simple and attributed to Pythagoras himself. The figure breaks a square down into five parts: four right triangles at the corners and a square whose sides are the four hypotenuses. Duly reorganised (Figure $\mathbf{3 b}$ ), these pieces form four right triangles and two squares built over the legs. The Pythagorean theorem is obtained by subtracting the four right triangles from the figure.

The second sample proof, intended for the most advanced level, was put forward by Indian mathematician Bhāskara (11141185). Given a right triangle with legs $A$ and $B$ and hypotenuse $C$, the first configuration (Figure $4 a$ ) shows a square with side $C$ divided into five parts. These pieces can be reorganised to form another figure (Figure $\mathbf{4 b}$ ), consisting in two squares, one with side $A$ and the other with side $B$. A comparison of these areas yields the desired result: $C^{2}=A^{2}+B^{2}$. 

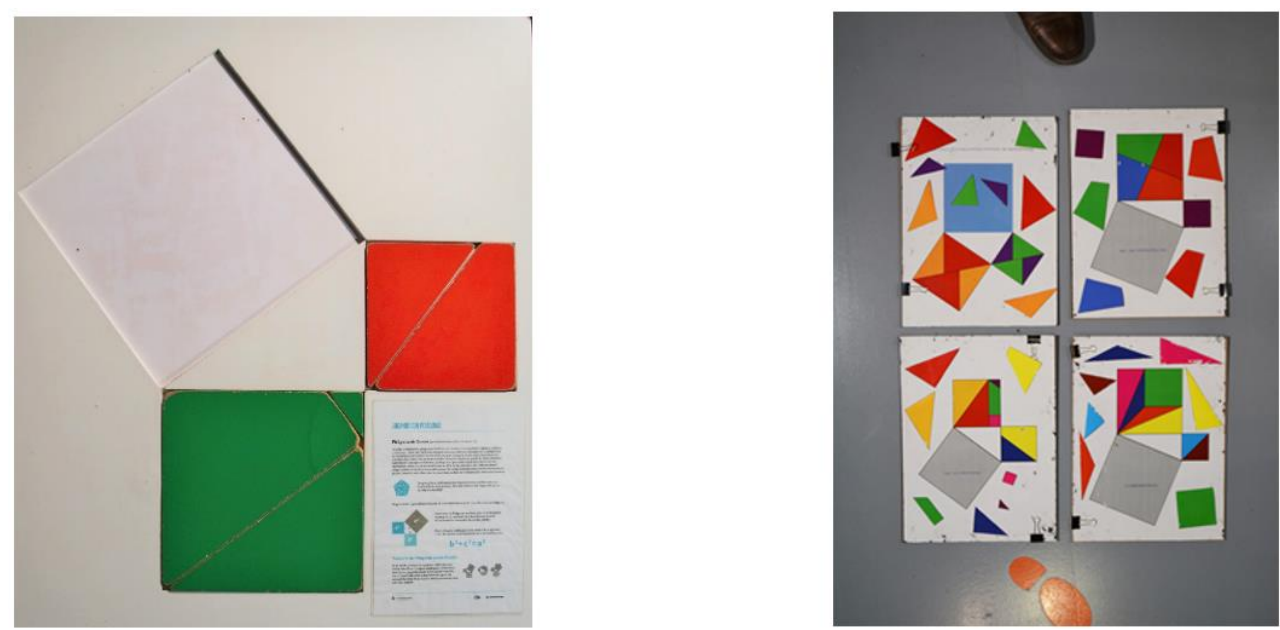

Figure 5. Implementation of puzzles of the Pythagorean theorem's proofs

Table 2. Contribution of the pre-visit, module, and post-visit stages to van Hiele levels and Hoffer skills

\begin{tabular}{|c|c|c|c|c|}
\hline Skill|Level & $\begin{array}{c}\text { Level } 1 \\
\text { Visualisation }\end{array}$ & $\begin{array}{l}\text { Level } 2 \\
\text { Analysis }\end{array}$ & $\begin{array}{c}\text { Level } 3 \\
\text { Abstraction }\end{array}$ & $\begin{array}{c}\text { Level } 4 \\
\text { Deduction }\end{array}$ \\
\hline Visual & $\begin{array}{c}\text { Pre-visit } \\
\text { Module (activities } 1 \text { and 3) }\end{array}$ & $\begin{array}{c}\text { Pre-visit } \\
\text { Module (activities 1, 2, and 3) }\end{array}$ & Module (activities 1, 2 and 3) & $\begin{array}{c}\text { Module (activities } 2 \text { and } 3 \text { ) } \\
\text { Post-visit }\end{array}$ \\
\hline Verbal & $\begin{array}{c}\text { Pre-visit } \\
\text { Module (activities } 1 \text { and } 3 \text { ) }\end{array}$ & $\begin{array}{c}\text { Pre-visit } \\
\text { Module (activities } 1 \text { and 3) }\end{array}$ & $\begin{array}{l}\text { Module (activity 3) } \\
\text { Post-visit }\end{array}$ & Post-visit \\
\hline Drawing & Pre-visit & Pre-visit & Post-visit & Post-visit \\
\hline Logical & $\begin{array}{c}\text { Pre-visit } \\
\text { Module (activities } 1 \text { and 3) }\end{array}$ & $\begin{array}{c}\text { Pre-visit } \\
\text { Module (activities 1, 2, and 3) }\end{array}$ & $\begin{array}{l}\text { Module (activities } 2 \text { and } 3 \text { ) } \\
\text { Post-visit }\end{array}$ & Post-visit \\
\hline Applied & $\begin{array}{c}\text { Pre-visit } \\
\text { Module (activities } 1 \text { and 3) } \\
\text { Post-visit }\end{array}$ & $\begin{array}{c}\text { Pre-visit } \\
\text { Module (activities } 1 \text { and 3) } \\
\text { Post-visit }\end{array}$ & Post-visit & Post-visit \\
\hline
\end{tabular}

The collection of puzzles is completed with proofs, readily adapted to manipulatives, authored by Liu Hi (China, $300 \mathrm{CE}$ ), Thâbit Ibn Qurra (826-901), Leonardo da Vinci (1452-1519), Henry Perigal (1801-1898), Frédéric Ozanam (1813-1853), AnaricioGöpel (around 1824), Johannes Eduard Böttcher (1847-1919), and Elisha Scott Loomis (1852-1940). They are all included in Loomis's (1968) or González Urbaneja's (2008) compilations. In Figure 5 you can see some of the implementations of the puzzles carried out in the museum.

Students at all levels are encouraged throughout to explore the proofs, while the language for each level is also introduced. This activity covers level 2, 3, and 4 visual skills and level 2 and 3 logical skills.

\section{Third interaction with the module: Pooling}

The two preceding activities entail working on van Hiele phases 2 (guided orientation) and 3 (explanation). Upon finalisation, a third focusing on phase 3 (explanation) is proposed. In this activity students share their visions of the structures observed (angles, triangles, legs, areas, and perimeters), building on their experience.

Pooling is an activity that can benefit visitors at any van Hiele level of reasoning. Some level 1 visitors, for instance, may try to identify the square of the length of the sides with the area of the respective squares and verbalise the Pythagorean theorem. Higher level visitors are invited to jointly compare the proofs and reflect on whether they are valid for all right triangles. This exercise also reveals whether the activity encourages them to find a generalised version of these proofs or devise a more formal proof.

This activity is associated primarily with verbal and logical skills in the first three levels, applied skills in the first two levels and visual skills in all four levels.

\section{STAGE 3: Post-visit}

This stage covers van Hiele phases 4 (self-orientation) and 5 (integration). Students are faced with more complex challenges that may be solved in a number of ways. Acting on their own, they find that many of the relationships among the objects of study are explicit. The activity also reviews and summarises what has been learnt.

In this stage, conducted in the classroom, activities can be proposed that introduce the Pythagorean theorem into other realms, enabling students to apply it to solve real life problems whose difficulty can be scaled to their level of reasoning. Software packages such as Cabri or GeoGebra can also be used to reproduce and compare proofs of the Pythagorean theorem.

This stage covers level 3 and 4 verbal, drawing and logical skills and applied skills for all levels. 


\section{DISCUSSION}

Starting from the role that museums can play in the teaching-learning process in the scientific-technological field, especially if the visit is properly structured and included in the curriculum. The van Hiele model together with the categorization of the skills for the acquisition of geometric abilities, provide us the theoretical framework for the development of mathematics modules. The Pythagorean theorem is one of the most famous in history. In addition to appearing in the high school mathematics curriculum, throughout history, research has been developed in the field of education, development of demonstrations used as a didactic tool based on comparison of areas, that lend themselves to developing manipulative activities, such as, in the form of a puzzle.

\section{Analysis of Proposal}

The proposal is analysed two-dimensionally in the table below, which shows the pre-visit, module and post-visit stages from which visitors characterised by each van Hiele level and Hoffer skill would benefit.

As Table 2 shows, the visit as a whole is designed to help visitors work on their skills, irrespective of their level of reasoning. Van Hiele level 1 visitors may benefit, for instance, from module activities 1 and 3 to work on visual, verbal, logical and applied skills, whilst level 2 students could benefit from the level 1 skills learnt and activity 2 by working on visual and logical skills. Visitors with higher van Hiele levels can work on the Hoffer skills both during and after the visit.

\section{Reflection}

The volume of research on teaching science in museums has risen steeply in recent years (Allen, 2004; Falk \& Dierking, 2013). The number of mathematics museums has also grown significantly of late, although their impact on mathematics learning has been scantly studied. Hence the need for tools with which to design and assess proposals for mathematics teaching in this nonformal context.

As Guisasola and Moretin (2007) point out, students' visits to science museums must be integrated into lesson planning for learning to be truly effective. It is therefore of great importance that teachers who organize these visits with their students prepare and adapt the museum's offerings to their own teaching objectives. The work presented here is a contribution in this direction. Specifically, a proposal for the design of an interactive module aimed at learning mathematics content has been carried out, exemplifying it for the case of the Pythagorean theorem. This proposal contributes in the direction of bridging the gaps between curricular and non-formal mathematical learning, which has already been explored by other authors in the field of science learning (Chin, 2004; Guisasola \& Morentín (2015b).

Under the proposal presented here, the van Hiele model would be used to design interactive modules for mathematics in museums. This model, a benchmark for all levels of mathematics instruction, provides a theoretical basis for the most effective design of such modules from a learning perspective. Specifically, along the lines suggested by Guisasola and Morentín (2015a), the module has been structured to include pre- and post-visit activities to reinforce the contents seen in the museum. In our proposal, the phases proposed in van Hiele's model (namely: information, guided orientation, explicitation, free orientation and integration (Jaime, 1993)), have been considered as a reference guide to structure the visit.

\section{CONCLUSIONS AND FUTURE LINES}

The paper explicitly characterises the van Hiele model based on its four levels and the related skills identified by Hoffer (1981). That characterisation is applied to design an interactive module for the Regional Government of Valencia's Museo Didáctico e Interactivo de Ciencias (MUDIC), taking the Pythagorean theorem as an example. The design of the module has been specified for the case of learning the Pythagorean theorem. First, a detailed analysis of the aspects derived from this mathematical content has been carried out for each of the van Hiele's levels, as well as their relationship with the different skills identified by Hoffer (1981). On the other hand, the activities proposed in the different phases of the visit have also been analysed in the previous terms. This detailed analysis has been focused on the content of the Pythagorean theorem but it is easily transferable to other content, so the proposal may serve as a reference for the design of future interactive museum modules and workshops in connection with any manner of mathematics content.

The van Hiele model (van Hiele, 1986), for learning geometry, proposes five phases that suggest to the teacher how to organize the contents in order to facilitate the progress of students from one level to another. In the last phase, Integration, students must acquire an overview of the contents and methods that have been worked on, relating the new knowledge with other fields, is what is currently known as STEAM strategy (Science, Technology, Engineering, Art, and Math). It would be interesting to implement this phase in the visit of the designed module, to learn about science in a multidisciplinary way, combining knowledge of subjects such as plastics, science, physics, chemistry, mathematics and technology, in addition to providing examples of application of scientific content in the daily life of visitors.

For future research it would be necessary to develop tools that allow us to assess the effectiveness of this proposal, so we consider it interesting to carry out the design, validation and implementation of questionnaires to know the beliefs of teachers in relation to learning mathematics in a museum and the effectiveness of this design to increase the science capital of the visitors.

Author contributions: All authors have sufficiently contributed to the study, and agreed with the results and conclusions.

Funding: No funding source is reported for this study.

Declaration of interest: No conflict of interest is declared by authors. 


\section{REFERENCES}

Allen, S. (2004). Designs for learning: Studying science museum exhibits that do more than entertain. Science Education, 88(1), 1733. https://doi.org/10.1002/sce.20016

Anderson, A. V., \& Thompson, V. (2001). Mathematics in science centers. Association of Science Technology Centers Inc. Available at: http://www.astc.org/resource/education/Math-SciCenters-Intro.pdf

Anderson, D., Lucas, K. B., \& Ginns, I. S. (2000). Development of knowledge about electricity and magnetism during a visit to a science museum and related post-visit activities. Science Education, 84(5), 658-679. https://doi.org/10.1002/1098237X(200009)84:5<658::AID-SCE6>3.0.CO;2-A

Anderson, D., Lucas, K. B., \& Ginns, I. S. (2003). Theoretical perspectives on learning in an informal setting. Journal on Research in Science Teaching, 40(2), 177-199. https://doi.org/10.1002/tea.10071

Arrieta, J., Álvarez, J. L., \& González, A. E. (1997). El teorema de Pitágoras a partir de la manipulación con geoplanos [The Pythagorean theorem from manipulation with geoplanes]. Revista Suma [Suma Magazine], 25, 71-86.

Barreto, J. (2009). Otras deducciones o extensiones del teorema de Pitágoras a lo largo de la historia como recurso didáctico [Other deductions or extensions of the Pythagorean theorem throughout history as a didactic resource]. Números: Revista de Didáctica de las Matemáticas [Issues: Journal of Mathematics Didactics], 70, 35-51.

Brajčić, M., Kovačević, S., \& Kuščević, D. (2013). Learning at the museum. Croatian Journal of Education, 15, 159-178.

Campillo, P. (1998). La noción de continuidad desde la óptica de los niveles de van Hiele [The notion of continuity from the perspective of van Hiele's levels] [Doctoral thesis, Universidad Politécnica de Valencia, España].

Chin, C. C. (2004). Museum experience-a resource for science teacher education. International Journal of Science and Mathematics Education, 2, 63-90. https://doi.org/10.1023/B:IJMA.0000026536.75034.34

Cooper, S. (2011). An exploration of the potential for mathematical experiences in informal learning environments. Visitor Studies, 14(1), 48-65. https://doi.org/10.1080/10645578.2011.557628

Crowley, M. L. (1990). Criterion-referenced reliability indices associated with the van Hiele geometry test. Journal for Research in Mathematics Education, 21(3), 238-241. https://doi.org/10.2307/749377

Falk, J. H. (1997). Testing a museum exhibition design assumption: Effect of explicit labeling of exhibit cluster on visitor concept development. Science Education, 81, 679-687. https://doi.org/10.1002/(SICI)1098-237X(199711)81:6<679::AID-SCE5>3.0.CO;2-F

Falk, J. H., \& Dierking, L. D. (2013). The museum. Experience revisited. Left Coast Press. https://doi.org/10.1080/10645578.2015.1016375

Faria, C., Guilherme, E., Gaspar, R., \& Boaventura, D. (2015). History of science and science museums: An enriching partnership for elementary school science. Science and Education, 24, 983-1000. https://doi.org/10.1007/s11191-015-9773-7

Flores, A. (1993). Pythagoras meets van Hiele. School Science and Mathematics 93(3), 152-157. https://doi.org/10.1111/j.19498594.1993.tb12214.x

González Urbaneja, P. M. (2008). El teorema llamado de Pitágoras. Una historia geométrica de 4.000 años [The so-called Pythagorean theorem. A 4,000-year geometric history]. Sigma, 32, 103-130.

Griffin, J., \& Symington, D. (1997). Moving from task-oriented to learning-oriented strategies on school excursions to museums. Science Education, 81(6), 763-779. https://doi.org/10.1002/(SICI)1098-237X(199711)81:6<763::AID-SCE11>3.0.CO;2-O

Guisasola, J., \& Morentín, M. (2007). ¿Qué papel tienen las visitas escolares a los museos de ciencias en el aprendizaje de las ciencias? Una revisión de las investigaciones [What role do school visits to science museums have in science learning? A review of the research]. Revista Enseñanza de las Ciencias [Science Teaching Magazine], 25(3), 401-414.

Guisasola, J., \& Morentín, M. (2015a). Primary and secondary teachers' ideas on school visits to science centres in the Basque Country. International Journal of Science and Mathematics Education, 13(S1), 191-214. https://doi.org/10.1007/s10763-0139481-1

Guisasola, J., \& Morentín, M. (2015b). The role of science museum field trips in the primary teacher preparation. International Journal of Science and Mathematics Education, 13, 965-990. https://doi.org/10.1007/s10763-014-9522-4

Guisasola, J., Morentín, M., \& Zuza, K. (2005). School visits to science museums and learning sciences: A complex relationship. Physics Education, 40(6), 544-549. https://doi.org/10.1088/0031-9120/40/6/006

Gurrola, F., \& Jáuregui, R. (2008). Didáctica del teorema de Pitágoras [Didactics of the Pythagorean theorem]. In R. Cantoral, F. Fasarelli, A. Garciadiego, A, R. Stein, \& C. Tzanakis (Eds.), Proceedings of History and Pedagogy Mathematics, The HPM Satellite Meeting of IMCE 11. Centro Cultural del México Contemporáneo.

Gutierrez, A., \& Jaime, A. (1998). On the assessment of the van Hiele levels of reasoning. Focus on Learning Problems in Mathematics, 20, 27-46.

Gyllenhaal, E. D. (2006). Memory of math: Visitors experiences in an exhibition about calculus. Curator: The Museum Journal, 49(3), 345-364. https://doi.org/10.1111/j.2151-6952.2006.tb00228.x

Hein, G. E. (1998). Learning in the museum. Routledge.

Hoffer, A. (1981). Geometry is more than proof. Mathematics Teacher, 74(1), 11-18. https://doi.org/10.5951/MT.74.1.0011 
Jaime, A. (1993). Aportaciones a la interpretación y aplicación del modelo de Van Hiele: La enseñanza de las isometrías del plano. La evaluación del nivel de razonamiento [Contributions to the interpretation and application of the Van Hiele model: The teaching of the isometries of the plane. The evaluation of the level of reasoning] [Doctoral thesis, Universidad de Valencia, España].

Jaime, A., \& Gutiérrez, A. (1990). Una propuesta de fundamentación para la enseñanza de la geometría: El modelo de van Hiele [A proposal of foundations for the teaching of geometry: The van Hiele model]. In S. Llinares, \& M. V. Sánchez (Eds.), Teoría y práctica en Educación Matemática [Theory and Practice in Mathematics Education], 295-398.

Janousek, I. (2000). The context museum: Integrating science and culture. Museum International 52(4), 21-24. https://doi.org/ 10.1111/1468-0033.00281

Kelton, M. L. (2015). Math on the move: A video-based study of school field trips to a mathematics exhibition [Doctoral thesis, San Diego State University University of California, San Diego].

Loomis, E. S. (1968). The Pythagorean proposition: Its demonstrations analyzed and classified, and bibliography of sources for data of the four kinds of proofs (Classics in mathematics education). National Council of Teachers of Mathematics.

McManus, P. M. (1992). Topics museums and science education. Studies in Science Education, 20, 157-182. https://doi.org/10.1080/ 03057269208560007

Nemirovsky, R., Kelton, M. L., \& Rhodehamel, B. (2013). Playing mathematical instruments: Emerging perceptuomotor integration with an interactive mathematics exhibit. Journal for Research in Mathematics Education, 44(2), 372-415. https://doi.org/ 10.5951/jresematheduc.44.2.0372

Pattison, S., Rubin, A., \& Wright, T. (2016). Mathematics in informal learning environment: A summary of the literature. Institute for Learning Innovation. Math in the Making Project. Available at: http://www.instituteforlearninginnovation.org/uploads/4/9/1/3/ 49134795/informalmathlitsummary_minm_03-23-16_v3.pdf

Pérez, M. A. (2009). Una historia de las matemáticas: Retos y conquistas a través de sus personajes [A history of mathematics: Challenges and conquests through its characters]. Editorial Visión Libros, Madrid.

Perry, D. L. (1992). Designing exhibits that motivate. ASTC Newsletter, 20(2), 9-10.

Popovic, G., \& Lederman, J. S. (2015). Implications of informal education experiences for Mathematics teachers' ability to make connections beyond formal classroom. School Science and Mathematics, 115(3), 129-140. https://doi.org/10.1111/ssm.12114

Rennie, L. J., \& Johnston, D. J. (2004). The nature of learning and its implications for research on learning from museums. Science Education, 88(S1), 4-16. https://doi.org/10.1002/sce.20017

Richey, R. C., Klein, J. D., \& Nelson, W. A. (2003). Development research: Studies of instructional design and development. In D. H. Jonassen (Ed.), Handbook of research for educational communications and technology (pp. 1099-1130). Lawrence Erlbaum Associates.

Salmi, H. (2003). Science centre as learning laboratories: Experiences of Heureka, the Finish Science Centre. Internat. Journal of Technology Management, 25(5), 460-476. https://doi.org/10.1504/IJTM.2003.003113

Sarasua, J. (2010). Hacia una categorización de los objetivos geométricos: Propuesta de nuevos descriptores de los niveles de van hiele para la representación externa de figuras planas [Towards a categorization of geometric objectives: Proposal of new descriptors of van ice levels for the external representation of plane figures] [Doctoral thesis, Universidad del País Vasco. España].

Suter, L. E. (2014. Visiting science museums during middle and high school: A longitudinal analysis of student performance in science. Science Education, 98(5), 815-839. https://doi.org/10.1002/sce.21116

Tuckey, C. (1992). Children's informal learning at an interactive science centre. International journal of Science Education, 14(3), 273-278. https://doi.org/10.1080/0950069920140304

Usiskin, Z. (1982). van Hiele levels and achievement in secondary school geometry. ERIC.

van Hiele, P. M. (1955). De niveau's in het denken, welke van belang zijn bij het onderwijs in de meetkunde iii de eerste kíasse van het V.H.M.O. [The levels of thought that are important in the education of geometry iii the first kíasse of the V.H.M.O.]. Paedagogische Stüdien, XXXII(J.B. Wolters: Groningen), 289-297.

van Hiele, P. M. (1986). Structure and insight: A theory of mathematics education. Academic Press.

Vargas, G., \& Gamboa, R. (2013). La enseñanza del teorema de Pitágoras: Una experiencia en el aula con el uso del geogebra, según el modelo de Van Hiele [Teaching the Pythagorean theorem: A classroom experience with the use of geogebra, according to the Van Hiele model]. Uniciencia [Uniqueness], 27(1), 95-118.

Wang, F., \& Hannafin, M. J. (2005). Design-based research and technology-enhanced learning environments. Educational Technology Research \& Development, 53(4), 5-23. https://doi.org/10.1007/BF02504682

Weiss-Pidstrygach, Y. (2007). Historical mathematical models in teacher education. Proceedings of the Seventh European Summer University ESU 7, 129-140.

Wright, T., \& Parkes, A. (2015). Exploring connections between physical and mathematical knowledge in science museums. Informal Learning Review, March/April, 16-21. 